\title{
Assessing the influence of the atmospheric oscillations on pelagic and highly migratory sharks bycatches from Spanish Mediterranean Sea, a meta-analytic approach
}

\author{
José Carlos Báez \\ 1 Instituto Español de Oceanografía, Centro Oceanográfico de Málaga, Puerto Pesquero Fuengirola (Málaga), Spain. \\ 2 Facultad de Ciencias de la Salud, Universidad Autónoma de Chile, Chile.
}

Correspondence

JC. Báez

E-mail: granbaez_29@hotmail.com

Received: 17 September 2014

Accepted: 27 February 2015

Published on-line: 24 March 2015

\section{Resumen}

Evaluación de la influencia de las oscilaciones atmosféricas sobre las capturas accesorias de tiburones pelágicos y altamente migratorios desde el Mediterráneo español, un enfoque metaanalítico

El objetivo principal del presente estudio fue analizar el efecto de las oscilaciones atmosféricas sobre los patrones de descarga de los tiburones pelágicos capturados de forma accesoria en palangre de superficie (fundamentalmente tintoreras, marrajos, y tiburones zorros) desde el Mediterráneo español, utilizando un enfoque meta-analítico. El objetivo final es conocer la respuesta de los tiburones altamente migratorios a los fenómenos climáticos de gran escala, y su posible relación con el efecto del calentamiento global. Se utilizaron dos fuentes de datos diferentes, ambas de áreas geográficas diferentes: mar de Alborán y mar Balear. Los resultados indican que la abundancia local de tiburones pelágicos podría estar mediada por la oscilación ártica.

Palabras clave: Oscilación ártica, Calentamiento Global, Oscilación del Atlántico Norte, tiburones.

\begin{abstract}
Blue shark, shortfin mako shark and the thresher sharks are the three taxa of pelagic sharks most caught as bycatch in the Spanish pelagic longline fishery from Mediterranean Sea. The main aim of the present study was to analyse the effect of atmospheric oscillations about landing patterns of blue shark, shortfin mako shark, and thresher sharks from Spanish Mediterranean Sea, using a metaanalytical approach. The ultimate goal was to understand the response of highly migratory sharks to large-scale climate phenomena, and its possible link with the effect of global warming. Two different data sources were used from different geographical areas: Alboran Sea and Balearic Sea. The results indicate that the local abundance of pelagic sharks could be mediated by the Arctic Oscillation.
\end{abstract}

Key words: Arctic Oscillation, Global warming, North Atlantic Oscillation, Sharks. 


\section{Introduction}

Evidence for severe declines in large predatory fishes is increasing around the world. For example, recent estimates suggest that populations of large sharks have declined regionally by $90 \%$ or more (Heithaus et al. 2008). According to Ferretti et al. (2008), Hammerhead (Sphyrna spp., Rafinesque, 1810), blue shark Prionace glauca (L., 1758), mackerel sharks, e.i. Isurus oxyrinchus Rafinesque, 1810 and Lamna nasus (Bonnaterre, 1788), and thresher shark Alopias vulpinus (Bonnaterre, 1788), declined between 96 and 99.99\% relative to their former abundance. According to World Conservation Union (IUCN) criteria, these species would be considered critically endangered.

Blue shark, shortfin mako shark, and the thresher sharks (including: Alopias superciliosus Lowe, 1841 and A. vulpinus) are the three taxa of pelagic sharks most caught as bycatch in the Spanish pelagic longline fishery from Mediterranean Sea (Megalofonou et al. 2005; Báez et al. 2009). Blue shark is the predominant shark species caught as bycatch in the drifting longline fisheries from Mediterranean Sea. Thus, in the Spanish surface longline fisheries in the Mediterranean targeting swordfish Xiphias gladius Linnaeus, 1758 from 1999 to 2001 represented 2\% of the total catch (Valeiras \& de la Serna 2003a, 2003b).

Alboran Sea showed the highest shark landings from the Mediterranean Sea (Castro et al. 1999, Valeiras et al. 2003a, Macías et al. 2004, Megalofonou et al. 2005), while there is a minimum from Strait of Sicilia (Megalofonou et al. 2005). These high bycatches of the sharks from Alboran Sea, could be probably related to its location, i.e. an important migratory channel, adjacent to the Atlantic Ocean (Megalofonou et al. 2005).

Blue shark, shortfin mako shark, and thresher sharks (Alopias sp.), are considered oceanic, pelagic, and highly migratory sharks. In this context, many authors have proposed to model the response of migratory species to large-scale climate phenomena, like the North Atlantic Oscillation (NAO), that integrate weather conditions over large areas, rather than local weather conditions (Forchhammer et al. 2002, Forchhammer \& Post 2004, Robison et al. 2009).

The NAO is related with the different pres- sures between the low pressure center, that is typically located near Iceland, and the high pressure center that is typically located over the Azores. NAO is responsible for most of the climatic variability in the North Atlantic region, modifying direction and intensity of Westerlies, and the location of anticyclones, which could affect to the marine ecosystems and fisheries from Mediterranean Sea (Vicente-Serrano \& Trigo 2011).

Another important atmospheric oscillation that drives the response of climate phenomena in the North Hemisphere is the Arctic Oscillation (AO). The AO refers to the pressure anomalies in the Arctic region, i.e., if this pressure system over the Arctic is weaker than normal atmospheric pressure, which results in weaker upper level winds, or if this pressure system over the Arctic is higher than normal atmospheric pressure, which forces cold air and storms to remain further north (Thompson \& Wallace 1998, Ambaum et al. 2001).

Both the NAO and AO describe the varying pressure gradients in the northern latitudes and the resultant effects on temperature and storm tracks across the continent. However, many authors have discussed if AO and NAO are two separate indices that are ultimately describing the same phenomenon (to see Thompson \& Wallace 1998, Thompson et al. 2000, Lohmann et al. 2005), or two different indices that are affected for the same causal external parameters (Frias et al. 2005, Baldwin et al. 2007, Báez et al. 2013a).

The main aim of the present study was to analyze the effect of atmospheric oscillation (NAO and $\mathrm{AO}$ ) on landing patterns of blue shark, shortfin mako shark, and thresher sharks (Alopias sp.) from Spanish Mediterranean Sea, using a metaanalytical approach. The ultimate goal was to understand of the response of highly migratory sharks to large-scale climate phenomena, and its possible link with the effect of global warming.

\section{Material and Methods}

For this study two different databases were used. On the one hand, the registered landings obtained for blue shark, shortfin mako shark, and thresher sharks (Alopias sp.) from the annual fisheries statistics published by the Junta de Andalucía (Andalusian Regional Government) (Galisteo et al. 
2001a, 2001b, 2002, 2004, 2005, Alonso-Pozas et al. 2007, Galisteo et al. 2007, 2008, 2009a, 2009b, 2011, 2012, 2013 and JAND 2013), available for the period between 2000-2013 from Mediterranean harbours; which imply Alboran Sea. On the other hand, the registered landings obtained for blue shark, shortfin mako shark, and thresher sharks (Alopias sp.) from FishStat (Fisheries Data Analysis Software for Windows ${ }^{\mathrm{TM}}$ ) provided by the Fisheries and Aquaculture Depart- ment of Food and Agriculture Organization of the United Nations (FAO), available from link: $\mathrm{http}$ ://www.fao.org/fishery/statistics/software/fishstatj/en (last accessed 15 May of 2014)

From FishStat the data landing of sharks reported for Spain from Balearic Sea fishing ground available for the period 1997-2011 were used. Thereby, two different data sources and from different geographical areas: Alboran Sea and Balearic Sea (Table 1).

\begin{tabular}{|c|c|c|c|c|c|c|c|c|c|c|c|c|}
\cline { 2 - 11 } \multicolumn{1}{c|}{} & Blue $_{\text {alb }}$ & Shortfin $_{\text {alb }}$ & Alopias $_{\text {alb }}$ & Blue $_{\text {bal }}$ & Alopias $_{\text {bal }}$ & shortfin $_{\text {bal }}$ & $\mathbf{N A O}$ & $\mathbf{N A O}_{\text {py }}$ & $\mathbf{N A O}_{\mathbf{w}}$ & $\mathbf{A O}$ & $\mathbf{A O}_{\text {py }}$ & $\mathbf{A O}_{\mathbf{w}}$ \\
\hline 1997 & n.a & n.a & n.a & 146,000 & 3,000 & 6,000 & -0.157 & -0.214 & -1.187 & -0.040 & -0.456 & -0.477 \\
\hline 1998 & n.a & n.a & n.a & 59,000 & 7,000 & 7,000 & -0.481 & -0.157 & 0.100 & -0.271 & -0.040 & 0.066 \\
\hline 1999 & n.a & n.a & n.a & 20,000 & 5,000 & 5,000 & 0.391 & -0.481 & 0.820 & 0.113 & -0.271 & 0.549 \\
\hline 2000 & 3,342 & 1,011 & 58 & 26,000 & 0 & 3,000 & 0.207 & 0.391 & -0.193 & -0.046 & 0.113 & -1.206 \\
\hline 2001 & 38,493 & 60,121 & 4,060 & 6,000 & 0 & 2,000 & -0.183 & 0.207 & -0.147 & -0.162 & -0.046 & 0.068 \\
\hline 2002 & 9,089 & 2,664 & 910 & 3,000 & 0 & 2,000 & 0.039 & -0.183 & -1.133 & 0.072 & -0.162 & -1.502 \\
\hline 2003 & 9,993 & 2,545 & 1,994 & 9,000 & 0 & 2,000 & 0.098 & 0.039 & 0.080 & 0.152 & 0.072 & 0.079 \\
\hline 2004 & 112,173 & 30,617 & 25,057 & 7,000 & 3,000 & 2,000 & 0.243 & 0.098 & 0.280 & -0.192 & 0.152 & 0.464 \\
\hline 2005 & 24,944 & 5,903 & 1,147 & 9,000 & 3,000 & 2,000 & -0.268 & 0.243 & -0.577 & -0.375 & -0.192 & -0.615 \\
\hline 2006 & 15,783 & 1,707 & 2,382 & 61,000 & 4,000 & 4,000 & -0.208 & -0.268 & -0.153 & 0.138 & -0.375 & 0.591 \\
\hline 2007 & 50,610 & 13,608 & 6,087 & 3,000 & 2,000 & 1,000 & 0.173 & -0.208 & 0.457 & 0.269 & 0.138 & 0.228 \\
\hline 2008 & 77,717 & 10,480 & 3,731 & 9,000 & 4,000 & 2,000 & -0.378 & 0.173 & -0.213 & 0.177 & 0.269 & 0.805 \\
\hline 2009 & 9,894 & 1,562 & 2,184 & 7,000 & 4,000 & 2,000 & -0.243 & -0.378 & -0.993 & -0.330 & 0.177 & -1.498 \\
\hline 2010 & 31,763 & 7,993 & & 39,000 & & 8,000 & -1.153 & -0.243 & -1.467 & -1.043 & -0.330 & -1.158 \\
\hline 2011 & 51,656 & 11,874 & & 59,850 & & 12,980 & 0.293 & -1.153 & 1.423 & 0.526 & -1.043 & 1.493 \\
\hline 2012 & 40,076 & 10,341 & & n.a & & n.a & -0.456 & 0.293 & -0.823 & -0.182 & 0.526 & -1.125 \\
\hline 2013 & 35,393 & $2,728.25$ & & n.a & & n.a & 0.210 & -0.456 & 0.190 & 0.001 & -0.182 & 1.256 \\
\hline
\end{tabular}

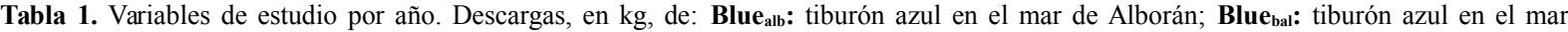

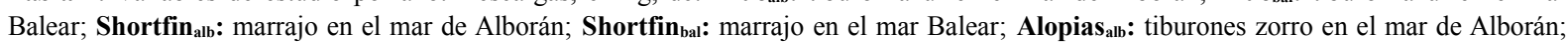
Alopias $_{\text {bal }}$ : tiburones zorro en el mar Balear. NAO: Oscilación del Atlántico Norte; NAO $\mathbf{p y}_{\mathrm{py}}$ : Oscilación del Atlántico Norte en el año anterior; $\mathbf{N A O}_{\mathrm{w}}$ : Oscilación del Atlántico Norte en el invierno anterior; AO: Oscilación Ártica; AO $\mathbf{p y}_{\text {: Oscilación Ártica en el año anterior; AO }}$ : Oscilación Ártica en el anterior invierno. n.a.: datos no disponibles.

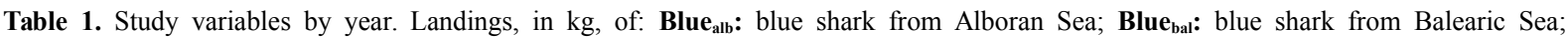

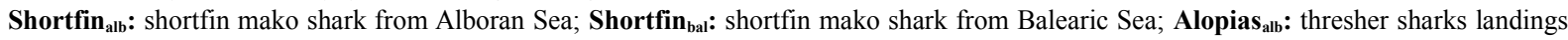

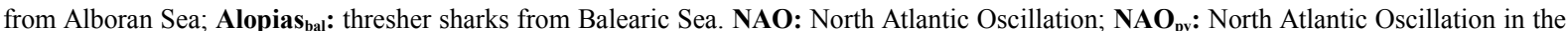
previous year; $\mathbf{N A O}_{\mathrm{w}}$ : North Atlantic Oscillation in the previous winter; AO: Arctic Oscillation; AOpy: Arctic Oscillation in the previous year; $\mathbf{A O}_{w}$ : Arctic Oscillation in the previous winter. n.a.: data not available.

Although, pelagic sharks have been reported as bycatch on trawl fisheries (e.g. Zeeberg et al. 2006), and tuna purse seines (for example Amandè et al. 2011) from other seas, in the Spanish trawl and purse seine Mediterranean fisheries it is an unusual bycatch. For example, Abad et al. (2007) did not report pelagic sharks as bycatch from trawl fisheries Alboran Sea, similarly Fromentin and Farrugio (2005) did not report any pelagic shark as bycatch from tuna purse seine fisheries from Mediterranean Sea. However, pelagic sharks are usually reported as bycatch of the Spanish drifting longline. Thereby, the surface drifting longline fisheries were considered as the significant origin of pelagic sharks landings reported. The Spanish surface longline fleet consists of approximately 151 vessels that fish on a year-round basis (BOE 59: 22308-22313; date 21/02/2014). Vessel length range from 12 to $27 \mathrm{~m}$ and fishing trips are often of short duration (one day to six days). A major description of these gears and fisheries are available in Camiñas et al. (2006), Báez et al. (2007a, b), García-Barcelona et al. (2010), and Báez et al. (2013b).

Alboran Sea showed the maximum value for the observed bycatches of pelagic sharks $(61.5 \%$ of the observed catches of blue shark, shortfin mako shark, and thresher sharks reported by Megalofonou et al. 2005), while Balearic Islands area showed $1.7 \%$ of the observed catches of blue 
shark, shortfin mako shark, and thresher sharks reported by Megalofonou et al. (2005).

Monthly values of the NAO index and AO index during the study period were taken from the website (from 1997 to 2012) of the National Oceanic and Atmospheric Administration: http://www.cpc.noaa.gov/products/precip/CWlink/ pna/nao index.html and http://www.esrl.noaa.gov/psd/data/correlation/ao.data, respectively.

The atmospheric oscillations present strong inter-annual and intra-annual variability; there is a strong NAO/AO pattern only in winter, primarily from November to March (Hurrell 1995). Moreover, several studies have shown that changes in $\mathrm{NAO} / \mathrm{AO}$ trends have a delayed effect on aquatic ecosystems due to ecosystem inertia (Báez et al., 2013a). For this reason, I compared landing of pelagic sharks (blue shark, shortfin mako shark, and thresher sharks), versus to the average NAO and $\mathrm{AO}$ index in the previous year $\left(\mathrm{NAO}_{\mathrm{py}}\right.$ and $\mathrm{AO}_{\mathrm{py}}$ hereafter), and during the winter prior to landing, i.e., since November to December from the previous year $\left(\mathrm{NAO}_{\mathrm{w}}\right.$ and $\mathrm{AO}_{\mathrm{w}}$ hereafter) (Table 1).

As a first step correlation between blue shark, shortfin mako shark, and thresher sharks landings from Balearic Sea and Alboran Sea was performed using Pearson correlation, having previously tested the normality of the variables using the Kolmogorov-Smirnov test of one sample (Sokal \& Rohlf 1995). In a second step, linear and non-linear regressions was performed to test the responses of blue shark, shortfin mako shark, and thresher sharks landings from Balearic Sea and Alboran Sea versus the independent variables $\mathrm{NAO}_{\mathrm{py}}, \mathrm{NAO}_{\mathrm{w}}, \mathrm{AO}_{\mathrm{py}}$ and $\mathrm{AO}_{\mathrm{w}}$. The best fit among was selected several significant regressions when different degrees of freedom were involved, in accordance with the highest $\mathrm{F}$-value.

\section{Results}

A significant positive correlation was found between blue shark landings versus thresher sharks landings from Alboran Sea $(r=0.851 ; \mathrm{df}=10 ; p=$ 0.002 ), blue shark landings versus shortfin mako shark landings from Balearic Sea $(r=0.579$; $\mathrm{df}=$ $15 ; p=0.024)$, and shortfin mako shark versus thresher sharks landings from Balearic Sea $(r=$ $0.618 ; \mathrm{df}=13 ; p=0.024)$.

There was a significant negative linear rela- tionship between blue shark landings $\left(\right.$ Blue $\left._{\text {bal }}\right)$ and shortfin mako shark (Shortfin ${ }_{\text {bal }}$ ) from Balearic Sea versus $A O_{\mathrm{py}}$, respectively, according to the functions (Figure 1 and 2):
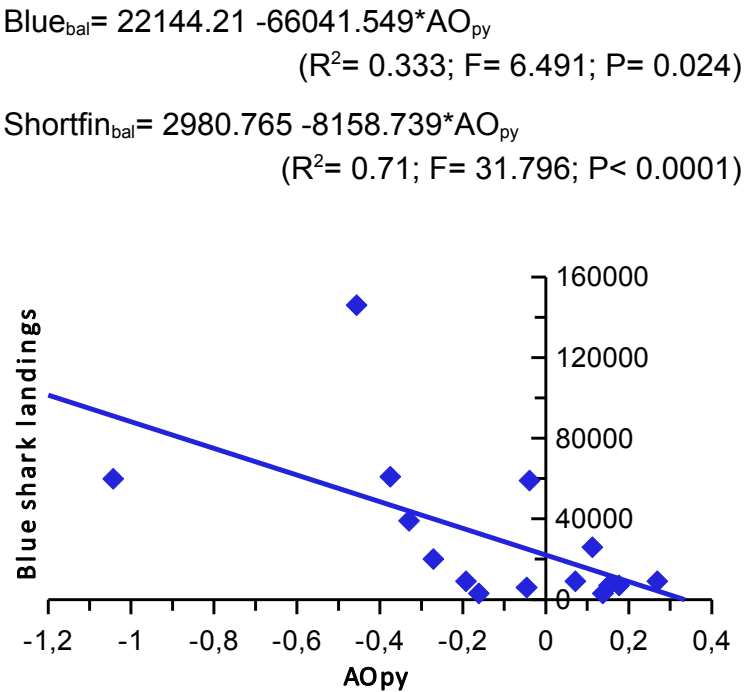

Figura 1. Relación lineal negativa entre descargas, en $\mathrm{kg}$, de tiburón azul del mar Balear y la Oscilación Ártica en el año anterior $\left(\mathrm{AO}_{\mathrm{py}}\right)$.

Figure 1. Negative linear relationship between blue shark landings, in $\mathrm{kg}$, from Balearic Sea versus Arctic Oscillation in previous year $\left(\mathrm{AO}_{\mathrm{py}}\right)$.

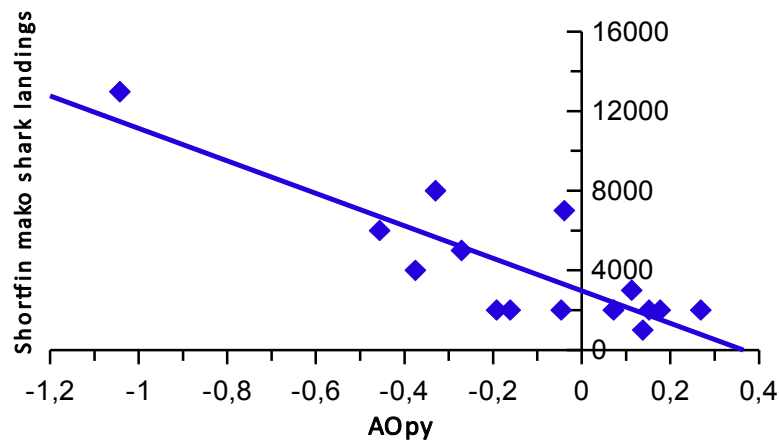

Figura 2. Relación lineal negativa entre descargas, en $\mathrm{kg}$, de marrajo del mar Balear y la Oscilación Ártica en el año anterior $\left(\mathrm{AO}_{\mathrm{py}}\right)$.

Figure 2. Negative linear relationship between shortfin mako shark landings, in $\mathrm{kg}$, from Balearic Sea versus Arctic Oscillation in previous year $\left(\mathrm{AO}_{\mathrm{py}}\right)$.

There was a significant positive exponential relationship between blue shark landings (Blue ${ }_{a l b}$ ) and thresher sharks landings (Alopias ${ }_{\text {alb}}$ ) from Alboran Sea versus $\mathrm{AO}_{\mathrm{w}}$, respectively, according to the functions (Figure 3 and 4):

$$
\begin{aligned}
& \text { Blue }_{a \mathrm{lb}}=27615.827^{\star} \mathrm{Exp}^{0.55^{*} \mathrm{AOw}} \\
& \left(R^{2}=0.342 ; F=6.234 ; P=0.028\right) \\
& \text { Alopias }_{\mathrm{alb}}=2772.87^{*} \operatorname{Exp}^{1.129^{*} \mathrm{AOW}} \\
& \left(R^{2}=0.402 ; F=5.371 ; P=0.049\right)
\end{aligned}
$$




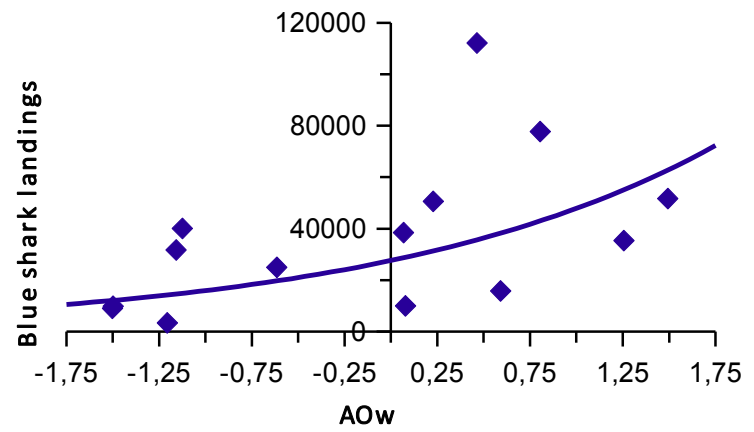

Figura 3. Relación exponencial positiva entre descargas, en $\mathrm{kg}$, de tiburón azul del mar de Alborán y la Oscilación Ártica en invierno $\left(\mathrm{AO}_{\mathrm{W}}\right)$.

Figure 3. Positive exponential relationship between blue shark landings in $\mathrm{Kg}$ from Alboran Sea versus Arctic Oscillation in winter $\left(\mathrm{AO}_{\mathrm{w}}\right)$

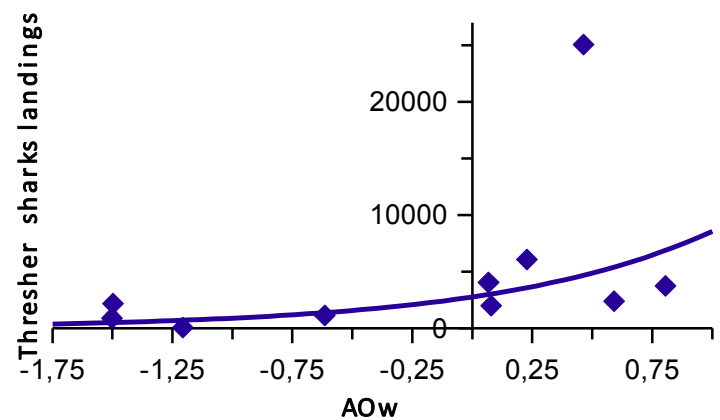

Figura 4. Relación exponencial positiva entre descargas, en $\mathrm{kg}$, de tiburones zorros del mar de Alborán y la Oscilación Ártica en invierno $\left(\mathrm{AO}_{\mathrm{W}}\right)$.

Figure 4. Positive exponential relationship between thresher sharks landings, in kg, from Alboran Sea versus Arctic Oscillation winter $\left(\mathrm{AO}_{\mathrm{w}}\right)$.

\section{Discussion}

The results indicate that the local abundance of blue shark and thresher sharks landings could be mediated by the AO. The AO index can be positive or negative. It is widely known that during the negative AO there are weak Westerlies over northern Europe, and storms develop over the Mediterranean region (Ginati \& Rosenfeld 2013). The hypothesis under study implies that the years with AO in negative phase, could increase supply of nutrients from the land to the sea in the area around the Balearic Sea. Given that several authors have shown that the Arctic Oscillation may be affected by the growing trend of global warming (Ginati \& Rosenfeld 2013, Krichak et al. 2014), the results could mean that changes in the $\mathrm{AO}$ index towards a positive rate (as predicted by the Atmospheric General Circulation Models) could affect the local abundance of pelagic sharks from Balearic Sea and Alboran Sea.

On the one hand, this study is limited by the fact that the landings involved different fishing efforts. Moreover, Alopias sp. series is limited to 2010 year, because since this year its fishing is prohibited according to the Spanish legislation (BOE 240: 84098-84099; date 05/X/2009). On the other hand, the negative relationships observed between blue shark landings and shortfin mako shark landings from Balearic Sea versus $\mathrm{AO}_{\mathrm{py}}$, and positive relationships observed between blue shark landings and thresher sharks landings from Alboran Sea versus $\mathrm{AO}_{\mathrm{w}}$ are very consistent, and they have to be taken in consideration. In this context, the two different databases used in this study (fisheries landings reported by Andalusian Regional Government, and FishStat Fisheries Data Analysis Software for Windows ${ }^{\mathrm{TM}}$ ) provide a useful tool, despite that they do not provide fishing effort.

There are two possible explanations in relation to these findings: i) negative $\mathrm{AO}$ phases increase in nutrients leads to an increase of productivity with a cascade effect on the entire food web of the area, increasing the number of prey of the swordfish, and thereby increase the fisheries effort in the area, or ii) negative AO phases increase in nutrients leads to an increase of productivity with a cascade effect on the entire food web of the area, increasing the number of prey of the pelagic sharks, begins a unidirectional flow of sharks individuals migrating to the Balearic Sea in detriment of near areas, such as the Alboran Sea.

Many studies indicate that the Spanish longline fleet is concentrated mainly around the Balearic Islands (Camiñas et al. 2006, Báez et al. 2007a, 2007b, García-Barcelona et al. 2010, Báez et al. 2013b). Thus, Alboran Sea was used by approximately $5 \%$ of the operative fleet; while Balearic Sea was used by approximately $80 \%$ of the operative fleet. Moreover, no correlation was found between landings of pelagic sharks (blue shark, shortfin mako shark, and thresher sharks) from Balearic Sea and Alboran Sea versus swordfish landings in both data sources.

The seasonality and migration pattern of blue shark have been studied by intensive tagging programs (for example, Fitzmaurice et al. 2005) or long-term electronic tagging experiments (for example, Vandeperre et al. 2014). These studies reported useful and real understanding on the 
migratory patterns of blue sharks, and how these patterns change across a blue shark's life history. In this context, blue shark undertakes very long distance migrations which cover long distances on the high seas. Their migrations are very complex, relating to prey availability and breeding cycles, with segregation by sex and reproductive stage (IUCN Species Survival Commission's Shark Specialist Group 2007).

Similarly, the shortfin mako shark is a very active fish that is highly migratory. Based on extensive tagging programs in the North Atlantic, it was observed that shortfin mako carry out extensive migrations of up to $4,542 \mathrm{~km}$. However, transatlantic migrations are not common for this species. Thus, the migration is limited to vicinity thereof (Mejuto et al. 2005, Valeiras \& Abad, 2006). Although, A. superciliosus and A. vulpinus are considered a highly migratory species, information about their movements are scarce (IUCN Species Survival Commission's Shark Specialist Group 2007).

In this context, future tagging programs of pelagic sharks should be conducted to test the hypothesis put forward in this study, and to understand the possible effects that global warming may have on the pelagic shark populations in the Mediterranean Sea.

\section{Acknowledgements}

J.C. Báez is supported from the PNDB project from Instituto Español de Oceanografía. This study was partially funded by the contract $\mathrm{n}^{\circ}$ 44/2013 with IUCN-Med in the framework of the project P00863-consultant "RAC/SPA MedOpen Seas": MoU n ${ }^{\circ}$ /RAC/SPA_2013 MedOpenSeas between RAC/SPA and IUCN-Med. I also thank Guillermo Ortuño Crespo and Dra. Carolina Johnstone their useful comments and English style corrections.

\section{References}

Abad E, Preciado I, Serrano A \& Baro J. 2007. Demersal and epibenthic assemblages of trawlable grounds in the northern Alborán Sea (western Mediterranean). Scientia Marina 71(3): 513-524.

Alonso-Pozas C, Arechavaleta A, Cobo R, Espinosa D, Galisteo A, García JJ, González F, Naranjo S, Nieto D, Raya L \& Rebollo J. 2007. Producción pesquera andaluza, año 2005. Consejería de Agricultura y
Pesca, Junta de Andalucía, Sevilla.

Ambaum MHP, Hoskins BJ \& Stephenson DB. 2001. Arctic Oscillation or North Atlantic Oscillation? Journal of Climate 14: 3495-3507.

Amandè MJ, Ariz J, Chassot E, Chavance P, Delgado de Molina A, Gaertner D, Murua H, Pianet R \& Ruiz J. 2011. By-catch and discards of the European purse seine tuna fishery in the Atlantic Ocean: estimation and characteristics for 2008 and 2009. Collective Volumen Scientific Papaper ICCAT 66(5): 21132120.

Báez JC, Gimeno L, Gómez-Gesteira M, Ferri-Yáñez F \& Real R. 2013a. Combined effects of the Arctic Oscillation and the North Atlantic Oscillation on Sea Surface Temperature in the Alborán Sea. PlosOne, 8(4): e62201. DOI:10.1371/journal.pone.0062201.

Báez JC, Macías D, Camiñas JA, Ortiz De Urbina JM, García-Barcelona S, Bellido JJ \& Real R. 2013b. Bycatch frequency and size differentiation in loggerhead turtles as a function of surface longline gear type in the western Mediterranean Sea. Journal of the Marine Biological Association of the U.K., 93: 1423-1427.

Báez JC, Real R \& Camiñas JA. 2007a. Differential distribution within longline transects of Loggerhead and Swordfish captured by the Spanish Mediterranean surface longline fishery. Journal of the Marine Biological Association of the U.K., 87: 801-803.

Báez JC, Real R, Camiñas JA, Torreblanca D \& GarciaSoto C. 2009. Analysis of swordfish catches and bycatches in artisanal longline fisheries in the Alboran Sea (Western Mediterranean Sea) during the summer season. Marine Biodiversity Records doi:10.1017/S1755267209990856.

Báez JC, Real R, García-Soto C, de la Serna JM, Macías D \& Camiñas JA. 2007b. Loggerhead turtle by-catch depends on distance to the coast, independent of fishing effort: implications for conservations and fisheries management. Marine Ecology-Progress Series 338: 249-256.

Baldwin MP, Dameris M \& Shepherd TG. 2007. How will the stratosphere affect climate change? Science 316: 1576-1577.

Camiñas JA, Báez JC, Valeiras J \& Real R. 2006. Differential loggerhead by-catch and direct mortality in surface longline according to boat strata and gear type. Scientia Marina 70: 661-665.

Castro J, de la Serna JM, Macías D \& Mejuto J. 1999. Preliminary scientific estimates of by-catch landings by the Spanish surface longline fleet in 1997 and 1998. Collective Volumen Scientific Papaper ICCAT 46(4): 1882-1894.

Ferretti F, Myers RA, Serena F \& Lotze HK. 2008. Loss of Large Predatory Sharks from the Mediterranean Sea. Conservation Biology 22(4): 952-964.

Fitzmaurice P, Green, P, Keirse G, Kenny M \& Clarke M. 2005. Stock discrimination of the blue shark, based on Irish tagging data. Collective Volumen Scientific Papaper ICCAT, 58(3): 1171-1178.

Forchhammer MC, \& Post E. 2004. Using large-scale climate indices in climate change ecology studies. Population Ecology, 46: 1-12 
Forchhammer MC, Post E, \& Stenseth NC. 2002. North Atlantic Oscillation timing of long- and short-distance migration. Journal of Animal Ecology, 71:1002-1014

Frias T, Trigo R, Valente M \& Pires C. 2005. The impact of the NAO and $\mathrm{AO}$ on the Iberian water resources. Geophysical Research Abstract 7: 16077962/gra/EGU05-A-04278.

Fromentin JM \& Farrugio H. 2005. Results of the 2003 observer program on board the French purse seiner targeting Atlantic bluefin tuna in the Mediterranean Sea. Collective Volumen Scientific Papaper ICCAT 58(2): 779-782

Galisteo A, García C \& Cruz I. 2001a. Producción pesquera andaluza, año 2000. Sevilla: Consejería de Agricultura y Pesca, Junta de Andalucía.

Galisteo A, García C, Cruz I \& Zurita F. 2001b. Evolución de la producción pesquera andaluza (19851999). Sevilla: Consejería de Agricultura y Pesca, Junta de Andalucía.

Galisteo A, García C \& Espinosa D. 2002. Producción pesquera andaluza, año 2001. Sevilla: Consejería de Agricultura y Pesca, Junta de Andalucía.

Galisteo A, González F, Naranjo S, Nieto D, Espinosa D, Alonso C, Arechavaleta A \& Cobo R. 2008. Producción pesquera andaluza, año 2006. Sevilla: Consejería de Agricultura y Pesca, Junta de Andalucía.

Galisteo A, González F, Naranjo S, Nieto D, Espinosa D, Alonso C, Arechavaleta A \& Cobo R. 2009b. Producción pesquera andaluza, año 2008. Sevilla: Consejería de Agricultura y Pesca, Junta de Andalucía.

Galisteo A, González F, Naranjo S, Nieto D, Espinosa D Alonso C, Arechavaleta A, Cobo R \& Valufo I. 2009a. Producción pesquera andaluza, año 2007. Sevilla: Consejería de Agricultura y Pesca, Junta de Andalucía.

Galisteo A, González F \& Nieto D. 2004. Análisis de la actividad extractiva de la flota andaluza por modalidades de pesca, año 2002. Sevilla: Consejería de Agricultura y Pesca, Junta de Andalucía.

Galisteo A, González F \& Nieto D. 2005. Valor añadido y pesca en Andalucía, año 2003. Sevilla: Consejería de Agricultura y Pesca, Junta de Andalucía.

Galisteo A, González F \& Nieto D. 2007. Valor añadido y pesca en Andalucía, año 2004. Sevilla: Consejería de Agricultura y Pesca, Junta de Andalucía.

Galisteo A, González F, Naranjo S, Abreu L, Losa MT, Alonso-Pozas C, Cobo R \& Espinosa D. 2011. Producción Pesquera Andaluza. Año 2010. Sevilla: Consejería de Agricultura y Pesca, Junta de Andalucía.

Galisteo A, González F, Naranjo S, Abreu L, Losa MT, Alonso-Pozas C, Cobo R \& Espinosa D. 2012. Producción pesquera andaluza. Año 2011. Junta de Andalucía. Sevilla: Consejería de Agricultura y Pesca. Secretaría General Técnica. Servicio de Publicaciones y Divulgación.

Galisteo A, González F, Naranjo S, Abreu L, Losa MT, Alonso-Pozas C, Cobo R \& Espinosa D. 2013. Producción pesquera andaluza. Año 2012. Junta de Andalucía. Sevilla: Consejería de Agricultura y Pesca. Secretaría General Técnica. Servicio de Publicaciones y Divulgación.
García-Barcelona S, Ortiz de Urbina JM, de la Serna JM, Alot E \& Macías D. 2010. Seabird by-catch in Spanish Mediterranean large pelagic logline fisheries, 1998-2008. Aquatic Living Resources 23: 363371.

Givati A \& Rosenfeld D. 2013. The Arctic Oscillation, climate change and the effects on precipitation in Is rael. Atmospheric Research 132-133: 114-124.

Heithaus MR, Frid A, Wirsing AJ \& Worm B. 2008. Predicting ecological consequences of marine top predator declines. Trend Ecology and Evolution 23(4): 202-210.

Hosmer DW \& Lemeshow S. 2000. Applied logistic regression. New York, Wiley.

Hurrell JW. 1995. Decadal trends in the North Atlantic Oscillation: Regional temperatures and precipitation. Science 269: 676-679.

IUCN Species Survival Commission's Shark Specialist Group. 2007. Review of Migratory Chondrichthyan Fishes. CMS Technical Series No. 15. Published by IUCN-The World Conservation Union, the United Nations Environment Programme (UNEP) and the Secretariat of the Convention on the Conservation of Migratory Species of Wild Animals (CMS). Bonn, Germany.

Krichak SO, Breitgand JS, Gualdi S \& Feldstein SB. 2014. Teleconnection-extreme precipitation relationships over the Mediterranean region. Theoretical and Applied Climatology 117: 679-692.

Lohmann G, Rimbu N, Dima M. 2005. Where can the Arctic oscillation be reconstructed? Towards a reconstruction of climate models based on stable teleconnections. Climate Past 1: 17-56.

Macías D, Gómez-Vives MJ \& de la Serna JM. 2004. Desembarcos de especies asociadas a la pesquería de palangre de superficie dirigido al pez espada (Xiphias gladius) en el mediterráneo durante 2001 y 2002. Collective Volumen Scientific Papers ICCAT 56(3): 981-986.

Megalofonou P, Yannopoulos C, Damalas D, De Metrio G, Deflorio M, de la Serna JM \& Macias D. 2005. Incidental catch and estimated discards of pelagic sharks from the swordfish and tuna fisheries in the Mediterranean Sea. Fisheries Bulletin 103: 620-634.

Mejuto J, García-Cortés B \& Ramos-Cartelle A. 2005. Tagging-recapture activities of large pelagic sharks carried out by Spain or in collaboration with the tagging programs of other countries. Collective Volumen Scientific Papers ICCAT 58(3): 974-1000

Junta de Andalucía 2013. Producción Pesquera 2013. Consejería de Agricultura, Pesca y Desarrollo Rural. Available at http://www.juntadeandalucia.es/agricul turaypesca/portal/servicios/estadisticas/estadisticas/ pesqueras/prodpesq2013.html (accessed on 15-V2014).

Robinson AR, Crick $H$, Learmonth JA, Maclean IMD, Thomas $C D$, Bairlein F, Forchhammer MC, Francis CM, Gill JA, Godley BJ, Harwood J, Hays GC, Huntley B, Hutson AM, Pierce GJ, Rehfisch MM, Sims DW, Santos MB, Sparks TH, Stroud DA \& Visser ME. 2009. Travelling through a warming world: climate change and migratory species. Endangered 
Species Research 7: 87-99.

Sokal RR \& Rohlf FJ. 1995. Biometry. 3rd edition. New York : W.H. Freeman and Co.

Thompson DWJ \& Wallace JM. 1998. The Arctic Oscillation signature in the wintertime geopotential height and temperature fields. Geophysical Research Letter 25: 1297-1300.

Thompson DWJ, Wallace JM \& Hegerl GC. 2000. Annular modes in the extratropical circulation: Part II: Trends. Journal of Climate 13: 1018-1036.

Valeiras J \& Abad E. 2006. Shortfin mako. ICCAT Manual. International Commision for the Consevation of Atlantic Tunas. Available at https://www.ic cat.int/Documents/SCRS/Manual/CH2/2_2_1_2_SM A_ENG.pdf (accessed on 15-V-2014).

Valeiras J \& de la Serna JM. 2003a. Contribución al estudio biológico de la tintorera (Prionace glauca) capturada accidentalmente en la pesquería de palangre de superficie de pez espada en el Mediterráneo occidental. Collective Volumen Scientific Papers ICCAT 55(1): 154-159.

Valeiras J, de la Serna JM, Macías D \& Alot E. 2003b. Nuevos datos científicos sobre desembarcos de especies asociadas realizados por la flota española de palangre de superficie en el Mediterráneo en 1999 y 2000. Collective Volumen Scientific Papers ICCAT 55(1): 149-153.

Vicente-Serrano SM \& Trigo RM (eds.). 2011. Hydrological, Socieconomic and Ecological impacts of the North Atlantic Oscillation in the Mediterranean Region. Advances in Global Change Research vol. 46. Londond: Springer.

Zeeberg J, Corten A \& de Graaf E. 2006. Bycatch and release of pelagic megafauna in industrial trawler fisheries off Northwest Africa. Fisheries Research 78: 186-195. 